\title{
The effect of fire on the dormancy break of three annual legume seeds
}

\author{
Fabio Gresta, ${ }^{1}$ Giovanni Avola, ${ }^{2}$ Rosalena Tuttobene, ${ }^{3}$ Andrea Onofri, ${ }^{4}$ Vincenzo Barrile, ${ }^{3}$ \\ Antonia Cristaudo, 5 Valerio Abbate ${ }^{2}$ \\ ${ }^{1}$ Dipartimento di Biotecnologie per il Monitoraggio Agroalimentare ed Ambientale, Università \\ Mediterranea di Reggio Calabria; ${ }^{2}$ CNR - Istituto per i Sistemi Agricoli e Forestali del \\ Mediterraneo, Catania; ${ }^{3}$ Dipartimento di Scienze delle Produzioni Agrarie e Alimentari, Università \\ di Catania; ${ }^{4}$ Dipartimento di Scienze Agrarie ed Ambientali, Università di Perugia; ${ }^{5}$ Dipartimento \\ di Biologia "Marcello La Greca", Università di Catania, Italy
}

\begin{abstract}
Fire is a common phenomenon in the Mediterranean environment and strongly influences vegetal population dynamics through its impact on vegetation and the soil seed bank. Fire is able to break down the seed coat of hard-seeded legumes within the soil and trigger germination. To evaluate the effect of fire on the dormancy break in Medicago ciliaris, Medicago rugosa and Scorpiurus muricatus subsp. subvillosus, the seeds were placed at three different depths (surface, $25 \mathrm{~mm}$ and $50 \mathrm{~mm}$ ) and subjected to fires at two different intensities (high and low). As a control sample, a batch of seeds was buried at 25 $\mathrm{mm}$ for the duration of the trial and not subjected to fire. Soil temperatures during the fire were compared directly to stubble quantity and indirectly related to soil depth. The two Medicago species survived exposure to $90^{\circ} \mathrm{C}$ for a few minutes and displayed a significant increase in germination with exposure to high temperatures (over $70^{\circ} \mathrm{C}$ ) for several minutes. On the other hand, no germination occurred in Scorpiurus, irrespective of treatment. In conclusion, fire had a significant and positive effect in triggering germination of the Medicago species, but the dispersal strategies of these hard-seeded legumes are only partially interrupted by fire as a large number of seeds (>50\%) remained non-germinated in the soil.
\end{abstract}

Correspondence: Fabio Gresta, Dipartimento di Biotecnologie per il Monitoraggio Agroalimentare ed Ambientale, Università Mediterranea di Reggio Calabria, Loc. Feo di Vito, 89122, Reggio Calabria, Italy.

Tel. +39.0965.801308 - Fax: +39.0965 .810569 .

E-mail: fgresta@unirc.it

Key words: fire, seed germination, annual legumes, dormancy break.

Received for publication: 8 October 2010.

Accepted for publication: 13 May 2011.

(C) Copyright F. Gresta et al., 2011

Licensee PAGEPress, Italy

Italian Journal of Agronomy 2011; 6:e23

doi:10.4081/ija.2011.e23

This work is licensed under a Creative Commons Attribution NonCommercial 3.0 License (CC BY-NC 3.0).

\section{Introduction}

Fire exerts an enormous influence on vegetation in the Mediterranean environment, together with other important variables (Geerling, 1985; Kozlowski, 2000) such as rainfall and herbivores (Mapaure and Campbell, 2002; Wiegand et al., 2006). Vegetation fires, both of natural or anthropogenic origin, occur not only in natural habitats but also in cultivated areas, and can have a great impact on the soil seed bank. The seed bank plays an essential role in the dynamics of plant communities (Leck et al., 1989), providing an immediate source of new vegetation after fire disturbances. In this context, the probability that a seed from the soil seed bank will germinate depends, directly and/or indirectly, on a number of fire-related factors such as heat shock (Keeley, 1994; Núñez and Calvo, 2000), changes in light regimes (Bell et al., 1999; Trabaud and Renard, 1999), smoke (Keeley and Fotheringham, 1998; Staden et al., 2000), ash (Henig-Sever et al., 1996; Reyes and Casal, 1998) and the release of nitrogen compounds (Henig-Sever, 1997; Keeley and Fotheringham, 1998). Exposure to elevated temperatures has been demonstrated to activate seeds that have a primary dormancy (Bell and Williams, 1998; Williams et al., 2004) and to break the physical barrier of hard-seeded legumes, releasing the seeds from tegumental dormancy (Bradstock and Auld, 1995; Smith et al., 2000). Heat diffusion into the topsoil depends on the fire intensity (magnitude and duration) and the soil characteristics (Bradstock and Auld, 1995; Williams et al., 2004). Fire intensity plays a key role in the rupturing of the seed coat (Auld and O'Connell, 1991); however, high intensity fire may burn the seed while low intensity fire may not be hot enough to break the dormancy of hard-seeded legumes (Saharjo and Watanabe, 1997). Soil characteristics also regulate the temperature and heat penetration, decreasing as depth increases and reacting differently depending on soil moisture and texture (Busse $e t$ $a l ., 2005)$. The major part of the research on this topic was carried out in laboratory conditions rather than in field situations, or was focused on bush-woody legume species (Danthu et al., 2003; Walters et al., 2004; Shackleton 2007), while less information is available on the effect of fire on the dormancy break in herbaceous hard-seeded legumes. Within this context, our paper explores the impact of fire intensity and seed position in the soil on the dormancy break of three annual legume species.

\section{Materials and Methods}

The trial was carried out in August 2007, in experimental plots of 4 
$\mathrm{m}^{2}(2 \mathrm{~m} \times 2 \mathrm{~m})$. Mature seeds of Medicago ciliaris L. All., Medicago rugosa Desr. and Scorpiurus muricatus subsp. subvillosus (L.) Thell., closed in wire mesh envelopes, were placed in clay soil at depths of 0 $\mathrm{mm}, 25 \mathrm{~mm}$ and $50 \mathrm{~mm}$, to simulate the stratification of seeds in field crops owing to the tillage. Two intensity controlled fires (low, LIF; high, HIF) were set up, created by burning two different amounts of wheat straw (corresponding to $2 \mathrm{~kg}$ in LIF and $4 \mathrm{~kg}$ in HIF per plot) to reproduce two field fire conditions. As a control, for each species a batch of seeds enveloped in the same manner was placed on the surface of the soil throughout the experiment, in a plot not subjected to fire. For each treatment (fire intensity and depth of burial), four envelopes, each containing 25 seeds, were used. Temperatures were recorded by thermocouples buried at tested depths and connected to a data logger. Immediately after the fire treatments, the envelopes were taken from the soil and the burnt seeds were counted and removed; those still intact were placed in $90-\mathrm{mm}$ diameter Petri dishes, on filter-paper soaked with $3 \mathrm{~mL}$ of distilled water. The Petri dishes were randomly arranged in a dark incubator (MCT 200, Angelantoni Scientifica, Perugia, Italy) set at $20 \pm 1^{\circ} \mathrm{C}$. Seeds were checked daily for 15 days, and those showing $2 \mathrm{~mm}$ of radicle emergence were considered to have germinated and removed from the Petri dishes. To check the viability of the non-germinated seeds (seeds that had not imbibed water), they were scarified with sandpaper at the end of the experiment.

\section{Statistical analyses}

The total percentage of seeds that germinated was calculated as the total number of seeds germinated divided by the total number of seeds taken for germination studies $\mathrm{x} 100$. Seed vigour was evaluated on the basis of the speed of germination, and the mean germination time (MGT) was calculated using the formula: MGT $=\Sigma(f x) / \Sigma x$, where $x$ is the number of daily germinated seeds, and $f$ is the number of days after the trial started (Ellis and Roberts, 1980). Both total percentage of germinated seeds and MGT were compared by using a nested ANOVA, considering the main effect of fire and of the depth within each level of fire. A graphical analysis of residuals showed that the basic assumptions for linear models were not severely violated and, thus, no stabilising transformation was adopted. In respect of marginality restriction, means for significant effects were compared by using the simulationbased procedure of Edwards and Berry (1987), which is practically equivalent to the Tukey test in the case of balanced data. Treatments in which none of the replicates showed any germination were excluded from the analysis because they would have hindered the data homoscedasticity.

\section{Results}

Soil temperatures and their temporal patterns varied widely with treatments during the fires (Figure 1). As expected, temperatures were higher at the surface of the soil, reaching a maximum of $95.3^{\circ} \mathrm{C}$ and $91.3^{\circ} \mathrm{C}$ in HIF and LIF fires, respectively, but with a shorter duration in LIF compared to HIF. In this last treatment, a temperature over $70^{\circ} \mathrm{C}$ was maintained for $20 \mathrm{~min}$, while in LIF this temperature was kept for 5 min only. At $25 \mathrm{~mm}$ depth, in HIF the maximum temperature $\left(60^{\circ} \mathrm{C}\right)$ was two thirds of that reached at the soil surface and almost one third of that shown in LIF $\left(31.6^{\circ} \mathrm{C}\right)$; moreover, temperatures over $50^{\circ} \mathrm{C}$ were maintained for $40 \mathrm{~min}$. At $50 \mathrm{~mm}$, the temperatures did not vary widely for either fire intensity, and ranged from $36.6^{\circ} \mathrm{C}$ of $\mathrm{HIF}$ to $30.4^{\circ} \mathrm{C}$ of LIF. The low germination of the seeds of the three studied species detected in the control group, ranging from $38 \%$ of $M$. ciliaris to $0 \%$ of $S$. muricatus, confirms the high levels of hard-seeded quality frequently encountered in legume species. The effect of fire on seed germination differed among the species and was particularly influenced by whether the seeds were buried or on the soil surface, except for Scorpiurus in which the seeds did not germinate, irrespective of treatments. The seeds of all species recovered from the soil surface when exposed to HIF fire were burnt and, consequently, after having been submitted to the germination trial, were classified as charred, nonviable seeds. In $M$. ciliaris, the HIF treatment significantly increased the germination of buried seeds, irrespective of the soil depth (Figure 2 ). This treatment induced a significantly greater germination ( $51 \%$ in an average of $25 \mathrm{~mm}$ and $50 \mathrm{~mm}$ depth) than found in the LIF (44\%) and the control (38\%) treatments. No significant difference was observed in relation to soil depth. In $M$. rugosa, LIF significantly increased the germination of seeds recovered from the soil surface (45\%), when compared to the control (25\%) and LIF x $25 \mathrm{~mm}(27 \%)$ treatments (Figure 3). Scarification of non-germinated seeds, done after the field experiment, resulted in full germination (data not reported), showing the presence of a consistent number of hard seeds. The lowest MGT values were recorded when the seeds were buried at 50 $\mathrm{mm}$ soil depth for $M$. ciliaris, irrespective of fire treatments, and at 50 $\mathrm{mm}$ in LIF treatment in $M$. rugosa (Figure 4).

\section{Discussion and Conclusion}

As expected, the temperatures caused by the fire vary greatly in magnitude and extent in relation to the soil depth considered. After the stubble fire, the temperatures peaked on the soil surface and decreased

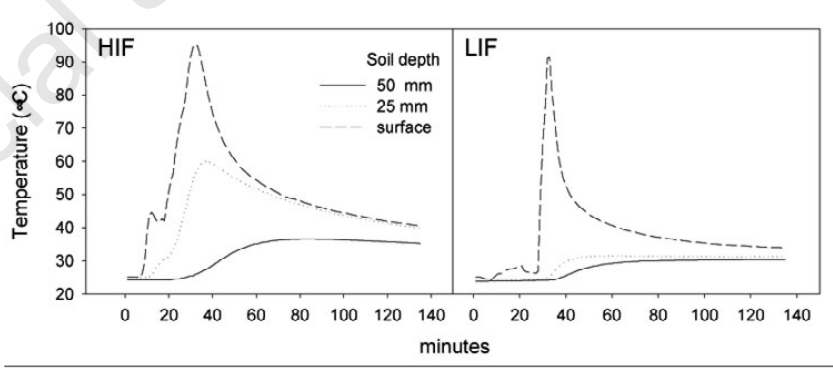

Figure 1. Temperatures during the fire experiment in relation to fire intensity and soil depth. HIF, high intensity fire; LIF, low intensity fire.

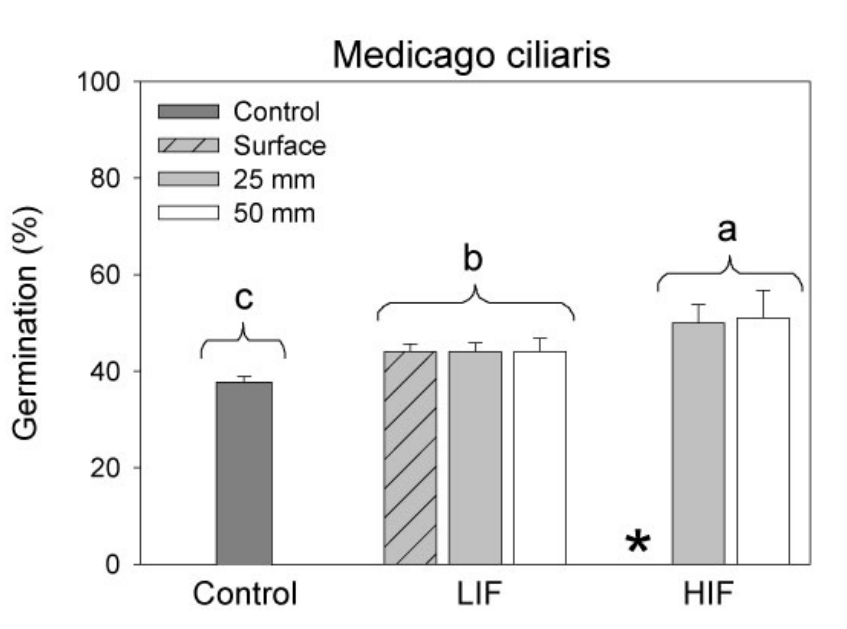

Figure 2. Total germination percentage in $M$. ciliaris and in the control, at the surface and at 25 and $50 \mathrm{~mm}$ soil depth. HIF, high intensity fire; LIF, low intensity fire; ${ }^{*}$ no germination occurs owing to the burning of seeds. Different letters indicate a significant difference for $\mathbf{P}<0.05$. 
as the depth in the soil increased (Patten and Cave, 1984; Bradstock et al., 1992). The patterns of soil temperatures during the fires appear to be directly related to stubble quantity and indirectly related to depth.

Legume seeds frequently have hard, impermeable, seminal teguments, which ensure long-term survival and dispersal strategies (Danthu et al., 1996; Vassal, 1998). Many studies have confirmed a release of seed coat-induced dormancy in legume seeds after fire

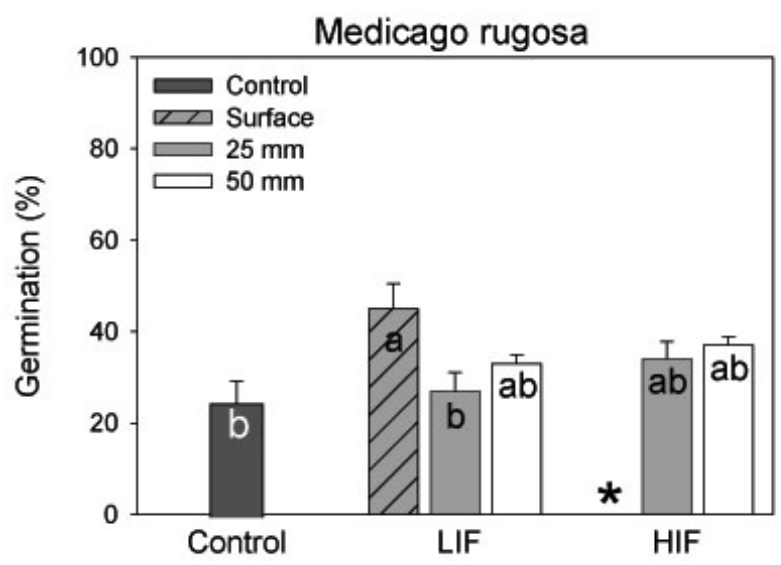

Figure 3. Total germination percentage in $M$. rugosa and in the control, at the surface and at 25 and $50 \mathrm{~mm}$ soil depth. HIF, high intensity fire; LIF, low intensity fire; *no germination occurs owing to the burning of seeds. Different letters indicate a significant difference for $\mathbf{P}<0.05$.

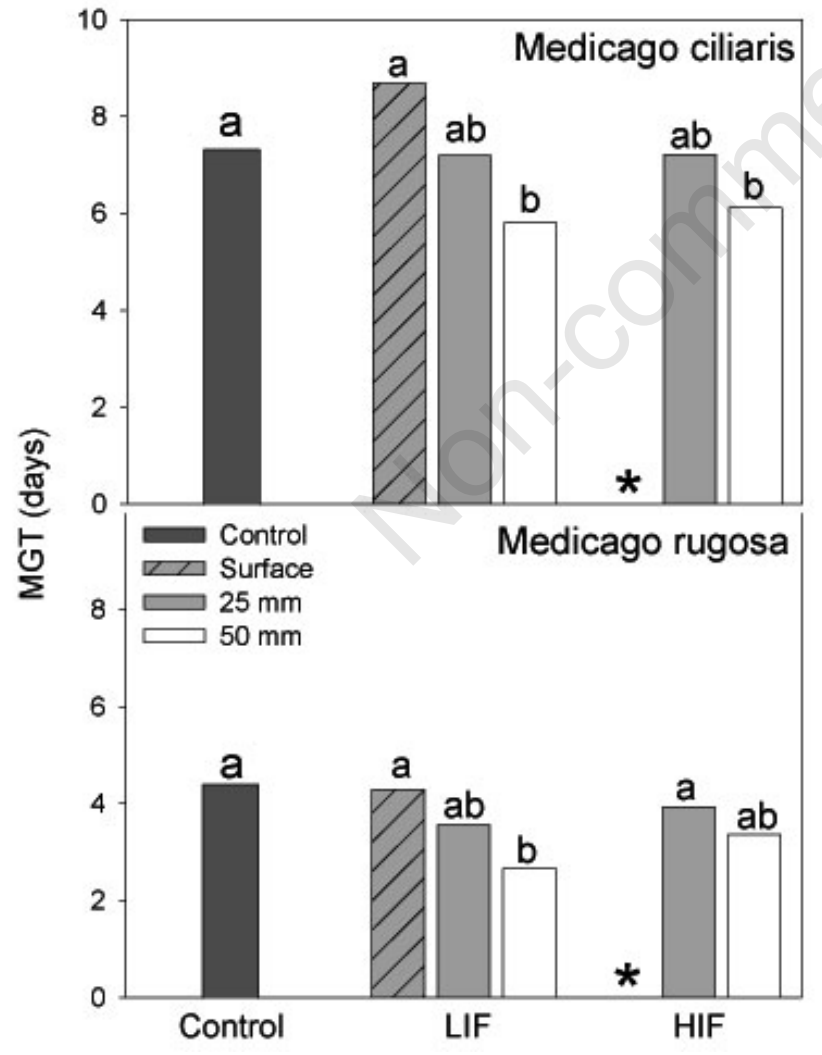

Figure 4. Mean germination time of the studied species in relation to the control, at the surface and at $25 \mathrm{~mm}$ and $50 \mathrm{~mm}$ soil depth. HIF, high intensity fire; LIF, low intensity fire. Different letters indicate a significant difference for $P>0.05$.
(Sabiiti and Wein, 1987; Mbalo and Witkowski, 1997). Heat shock, in fact, provoked by the passage of fires is one of the natural factors that trigger seed germination (Oba, 1990; Tarrega et al., 1992; Cox et al., 1993). However, the seed coat fracture as a result of fire and the following germination depend on the fire's intensity (temperature, duration) and on the species of seed. Conversely, some studies indicated the negative impact of fire on seed germination while others reported minimal or no effect (Brown, 1993; Van Staden et al., 1994). Thus, the questions are: i) do different hard-seeded legume species have the same response to heat shock? ii) which combination of temperature and soil depth is needed to perpetuate seed germination?

From our study, a clear indication has emerged of how fire breaks the seed dormancy in the two studied Medicago species but not in $S$. muricatus, which is in agreement with other authors (Herranz et al., 1998). Fire causes an increase of germination of $90 \%$ in $M$. rugosa and $26 \%$ in $M$. ciliaris after exposure to temperatures between $70^{\circ} \mathrm{C}$ and $90^{\circ} \mathrm{C}$ when compared to the control, which is consistent with the findings of other researchers (Auld and 0'Connell 1991; Jhurree et al., 1998). Exposure to temperatures between $80^{\circ} \mathrm{C}$ and $100^{\circ} \mathrm{C}$ has been shown to break the seed dormancy of several legumes of eucalypt savannas in north-eastern Australia, but temperatures greater than $100-120^{\circ} \mathrm{C}$ are shown to be lethal to seeds of these species (Williams et al., 2003). In our trial, fire intensity and consequently high temperature duration greatly influenced the chance of seed survival during fires. The two Medicago species survived exposure to $90^{\circ} \mathrm{C}$ for a few minutes and exhibited a significant increase in germination with exposure to high temperatures (over $70^{\circ} \mathrm{C}$ ) for several minutes. This suggests the ability of seeds to tolerate the passage of fire, and provides evidence of a stimulatory effect of the heat on germination. In Scorpiurus, the lack of an effect of fire in triggering germination is probably a result of a greater hardness of the seed coat (Gresta et al., 2007; Abbate et al., 2010), which is not fissured by a high intensity fire when it is buried and which is burnt when it is on the surface of the soil. All seeds on the soil surface were destroyed during exposure to HIF fire. Clearly, the burial of seeds reduces the negative impact of fires, as well as of predation (Miller, 1994). In conclusion, the fire had a significant and positive effect in triggering germination of Medicago species, but the dispersal strategies of these hard-seeded legumes is only partially interrupted by fire as a great number of seeds $(>50 \%)$ remained non-germinated in the soil.

\section{References}

Abbate V., Cristaudo A., Maugeri G., Gresta F., 2010. Scorpiurus muricatus L. subsp. subvillosus L. Thell., a potential forage legume species for the Mediterranean environment: a review. Grass Forage Sci. 65:2-10.

Auld T.D., O'Connell M.A., 1991. Predicting patterns of post-fire germination in 35 eastern Australian Fabaceae. Aust. J. Ecol. 16:53-70.

Bell D.T., King L.A., Plummer J.A., Taylor S.K., 1999. Ecophysiological effects of light quality and nitrate on seed germination in species from Western Australia. Aust. J. Ecol. 24:2-10.

Bell D.T., Williams D.S., 1998. Tolerance of thermal shock in seeds. Aust. J. Bot. 46:221-233.

Bradstock R.A., Auld T.D., 1995. Soil temperatures during experimental bushfires in relation to fire intensity: consequences for legume germination and fire management in south-eastern Australia. J. Appl. Ecol. 32:76-84.

Bradstock R.A., Auld T.D., Ellis M.E., Cohn J.S., 1992. Soil temperatures during bushfires in semi-arid, mallee shrublands, Aust. J. Ecol. 17:433-440.

Brown N.A.C., 1993. Promotion of germination of fynbos seeds by plant- 
derived smoke. New Phytol. 123:575-583.

Busse M.D., Hubbert K.R., Fiddler G.O., Shestak C.J., Powers R.F., 2005. Lethal soil temperatures during burning of masticated forest residues. Int. J. Wildland Fire 14:267-276.

Cox J.R., Alba-Avila A., Rice R.W., Cox J.N., 1993. Biological and physical factors influencing Acacia constricta and Prosopis velutina establishment in the Sonoran Desert. J. Range Manage. 46:43-48.

Danthu P., Ickowicz A., Friot D., Manga D., Sarr A., 1996. Effet du passage par le tractus digestif des ruminants domestiques sur la germination des graines de légumineuses ligneuses des zones tropicales sèches. Revue Elev. Méd. Vét. Pays Trop. 49:235-242.

Danthu P., Ndongo M., Diaou M., Thiam 0., Sarr A., Dedhiou B., Ould Mohamed Vall A., 2003. Impact of bush fire on germination of some West African acacias. Forest Ecol. Manag. 173:1-10.

Edwards D., Berry J.J., 1987. The efficiency of simulation based multiple comparisons. Biometrics 43:913-928.

Ellis, R.H., Roberts E.H., 1980. Towards a rational basis for testing seed quality. In: P.D. Hebblethwaite (ed). Seed Production. Butterworths, London, pp 605-635.

Geerling C., 1985. The status of the woody species of Sudan and Sahel zones of West Africa. Forest Ecol. Manag. 13:247-255.

Gresta F., Avola G., Abbate V., 2007. Germination ecology of Scorpiurus subvillosus L. seeds: the role of temperature and storage time. Plant Ecol. 190:123-130.

Henig-Sever N., 1997. Regulation of germination by ash and its ecological significance in post-fire germination of Mediterranean vegetation. PhD Thesis, Tel Aviv University, Tel Aviv, Israel.

Henig-Sever N., Eshel A., Ne'eman G., 1996. pH and osmotic potential of pine ash as post-fire germination inhibitors. Physiologia Plantarum 96:71-76.

Herranz J.M., Ferrandis P., Martínez-Sánchez J.J., 1998. Influence of heat on seed germination of seven Mediterranean Leguminosae species. Plant Ecol. 136:95-103.

Jhurree B., Bellairs S.M., Hetherington S.E., 1998. Germination and dormancy release of seeds of Australian native understorey species used for minesite rehabilitation. Seed Sci. Technol. 26:587-601.

Keeley J.E., 1994. Seed-germination patterns in fire-prone Mediterranean climate regions. In: M.T.K. Arroyo, P.H. Zedler and M.D. Fox (eds.) Ecology and Biogeography of Mediterranean Ecosystems in Chile, California and Australia. Springer-Verlag, New York, USA, pp 239-273

Keeley J.E., Fotheringham C.J., 1998. Mechanism of smoke-induced seed germination in a post-fire chaparral annual. J. Ecol. 86:27-36.

Kozlowski T.T., 2000. Response of woody plants to human-induced environmental stresses: issues problems under strategies for alleviating stress. Crit. Rev. Plant Sci. 19:91-170.

Leck M.A., Parker V.T., Simpson R.L., 1989. Ecology of Soil Seed Banks. Academic Press Inc., San Diego, CA, USA.

Mapaure I.N., Campbell B.M., 2002. Changes in miombo woodland cover in and around Sengwa Wildlife Research Area, Zimbabwe, in relation to elephants and fire. Afr. J. Ecol. 40:212-219.

Mbalo B.A., Witkowski E.T.F., 1997. Tolerance to soil temperatures experienced during and after the passage of fire in seeds of Acacia karroo, A. nilotica and Chromolaena odorata: a laboratory study. S. Afr. J. Bot. 63:421-425.

Miller M.F., 1994. The fate of mature African Acacia pods and seeds during their passage from the tree to the soil. J. Trop. Ecol. 10:183-196.

Núñez M. R., Calvo L., 2000. Effect of high temperatures on seed germination of Pinus sylvestris and Pinus halepensis. Forest Ecol. Manag. 131:183-190.

Oba G., 1990. Effects of wildfire on semi-desert riparian woodland along the Turkwel River, Kenya, and management implications for Turkana pastoralists. Land Degrad. Rehabil. 2:247-259.

Patten D.T., Cave G.H., 1984. Fire temperatures and physical characteristics of a controlled burn in the upper Sonoran desert. J. Range Manage. 37:277-280.

Reyes 0., Casal M., 1998. Germination of Pinus pinaster, P. radiata and Eucalyptus globulus in relation to the amount of ash produced in forest fires. Ann. For. Sci. 7:837-845.

Sabiiti E.N., Wein R.W., 1987. Fire and acacia seeds: a hypothesis of colonization success. J. Ecol. 74:937-946.

Saharjo B.H., Watanabe H., 1997. The effect of fire on the germination of Acacia mangium in a plantation in south Sumatra, Indonesia. Commonw. Forest. Rev. 76:128-131.

Shackleton C.M., 2007. The effects of fire on post-fire seed germination of selected Savanna woody species. Afr. J. Ecol. 45:545-549.

Smith M.A., Loneragan W.A., Grant C.D., Koch J.M., 2000. Effect of fire on the topsoil seed banks of rehabilitated bauxite mine sites in the Jarrah forest of Western Australia. Ecol. Manage. Restor. 1:50-60.

Staden J.V., Brown N.A.C., Jäger A.K., Johnson, T.A., 2000. Smoke as a germination cue. Plant Spec. Biol. 15:167-178.

Tarrega R., Calvo L., Trabaud L., 1992. Effect of high temperatures on seed germination of two woody Leguminosae. Vegetatio 102:139147.

Trabaud L., Renard P., 1999. Do light and litter influence the recruitment of Cistus spp. stands. Israel J. Plant Sci. 47:1-9.

Van Staden J., Kelly K.M., Bell W.E., 1994. The role of natural agents in the removal of coat-imposed dormancy in Dichrostachys cinerea (L.) Wight and Arn. seeds. Plant Growth Regul. 14:51-59.

Vassal, J., 1998. Les acacias au Sénégal. Taxonomie, écologie, principaux intérêts. In: C. Campa, C. Grignon, M. Guèye, S. Hamon (eds). L'acacia au Sénégal. Editions de l'ORSTOM, Paris, pp 15-33.

Walters M., Midgley J.J., Somers M.J., 2004. Effects of fire and fire intensity on the germination and establishment of Acacia karoo, Acacia nilotica, Acacia luederetizii, Dichrostachys cinerea in the field. BMC Ecol. 4:1-13.

Wiegand K., Saltz D., Ward D., 2006. A patch-dynamics approach to Savanna dynamics and woody plant encroachment: insights from an arid Savanna. Perspect. Plant Ecol. 7:229-242.

Williams P.R., Congdon R.A., Grice A.C., Clarke P.J., 2003. Fire-related cues break seed dormancy of legumes in tropical eucalypt savannas of north-eastern Australia. Austral. Ecology 28:507-514.

Williams P.R., Congdon R.A., Grice A.C., Clarke P.J., 2004. Soil temperature and depth of legume germination during early and late dry season fires in a tropical eucalypt savanna of north-eastern Australia. Austral. Ecology 29:258-263. 